\title{
Corporate Governance Of Family Firms In Subsequent Generations
}

Christine Duller, Johannes Kepler University, Austria

\begin{abstract}
This paper addresses the differences in corporate governance regarding generations of Austrian and German family businesses. Generations differ from each other significantly with respect to the percentage of non-family executives in management boards. The existence of a supervisory board differs between founder and subsequent generations, but it turns out that with transfer of ownership to subsequent generations, there is no noticeable trend concerning the percentage of nonfamily members in supervisory boards. Thus, this study demonstrates the importance of a comprehensive and profound analysis of generation-specific characteristics.
\end{abstract}

Keywords: Governance; Supervisory Board; Family Business; Generational Issues

\section{INTRODUCTION}

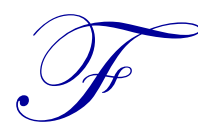

amily firms play an important role in most nations worldwide because they dominate the economic landscape, not only in terms of number, gross revenues, and jobs, but also because they are an important engine of growth, prosperity, and welfare as well (Heck and Trent, 1999; Astrachan and Shanker, 2003; Sirmon et al., 2008). Although various management issues in family firms have been analyzed, there are still aspects left for research, such as the relationship between family control and corporate governance structures and the influence of generations on these governance mechanisms. The organization of a family firm's management and supervisory boards, and the extent to which they are composed of external managers, can be regarded as examples of such governance mechanisms. The role of supervisory and advisory boards in family firms is a notable example of subject-matter that has been rarely studied (Koeberle-Schmid et al., 2009).

The influence of the incumbent generation of managers has received little attention in previous research. Indeed, the transition of family firms from one generation to the next and, in particular, the transition from the founder to the subsequent generation (Astrachan, 2003), has been identified as a salient field of research (Chrisman et al., 2003; Debicki et al., 2009). A question that is generally regarded as relevant, and yet less focused on, is to what extent governance structures and family influence affect the management or supervisory boards and how this influence differs with respect to the generation. Moreover, it is unclear whether there exist significant differences between first-generation family firms and subsequent generation family firms and whether these differences can be found only between the first and second generation or whether subsequent generations also differ among themselves.

Previous studies into generational issues of family firms have mainly been conceptual or otherwise qualitative (Beckhard and Dyer, 1983; Schein, 1983). They have also focused on the USA or the UK or have been restricted to selected areas (Davis and Harveston, 1999; Van den Berghe and Carchon, 2002; Suáre and SantanaMartín, 2004; Voordeckers et al., 2007; Bammens et al., 2008; Duller et al., 2011), or have rarely been concerned with differences between generations (Lussier and Sonfield, 2010). This work attempts to close this research gap by surveying this topic among Austrian and German family firms. This study provides a better understanding of generational similarities and differences, as well as the influence of generational issues on governance structures. 


\section{THEORETICAL BACKGROUND}

\section{Definition Of Family Firm}

Concerning the definition and classification of family firms, there is no general consensus in the literature (Chrisman et al., 2005; Ibrahim et al., 2008). An often used categorization is the Family Influence on Power, Experience, and Culture (F-PEC) scale developed by Astrachan et al. (2002). It consists of three subscales - power (the family's involvement in the firm), experience (the level of experience the family has in the business), and culture (the extent to which the firm's culture is a unique culture). The power-subscale is also known as the concept of Substantial Family Influence (SFI-concept) and is used to define family firms scientifically and practically in this study (Klein, 2000).

\section{Characteristics Of Family Firms From The Point Of View Of Various Theories}

Agency theory (Jensen and Meckling, 1976; Eisenhardt, 1989) describes settings in which one party - the principle - delegates actions to another party - the agent. It is assumed that the principle does not have complete information about the agent's actions and therefore costs arise for obtaining such information (Jacobides and Croson, 2001). All corporate governance instruments, in essence, serve to decrease agency costs by reducing this asymmetrical information or by harmonizing the interests of the principal and agent through an appropriate incentive structure (Witt, 2008). In family firms, ownership and management usually overlap to a certain extent; therefore, it is assumed that agency costs are lower in family-owned firms (Andersen et al., 2003; Anderson and Reeb, 2003; Bartholomeusz and Tanewski, 2006; Le Breton-Miller \& Miller, 2009).

Stewardship theory (Davis et al., 1997) assumes that managers and employees focus on cooperative or organizational goals and their possible contribution to these goals. Such altruistic and cooperative behaviour is supposed to be found in family firms (Dyer, 2003; Schulze et al., 2003; Karra et al., 2006; Ulaner et al., 2007; Le Breton-Miller and Miller, 2009; Vallejo, 2009). The implementation of formal corporate government mechanisms could have negative effects on mutual trust and intrinsic motivation (Davis et al., 1997).

\section{Impact Of Generation On Governance And Management Accounting: Hypotheses}

With the transfer of ownership to the next generation, the number of family members, who act passively and are mainly interested in their own economic welfare, increases (Lubatkin et al., 2005; Lane et al., 2006; Miller and Le-Breton-Miller, 2006). Furthermore, family ties weaken, which leads to a lower attachment to the firm (Salvato and Melin, 2008) and amongst family members (Jaskiewicz and Klein, 2007; Pieper et al., 2008). The number of generations involved in the firm increases the risk of conflicts among family members (Witt, 2008) and between family and non-family shareholders (Villalonga and Amit, 2006). Consistent with agency theory, in can be assumed that agency costs increase with transfer of the firm to subsequent generations (Lutz et al., 2010). The decreasing attachment of family members to the firm also means that the advantages of having a manager from the owner's family are reduced and the option of taking an external manager becomes more attractive.

The more passive role family members play in later generations, the fewer family members that will be available for managerial positions (Lussier and Sonfield, 2010), resulting in vacant positions in the management board that can be occupied by external managers.

In addition, various studies have shown that subsequent generations employ "more professional" management methods and that this professionalization goes hand in hand with a stronger involvement of non-family managers (Schein, 1983; Dyer, 1988). The preceding arguments result in the following hypothesis:

H1: As firm ownership is passed on to successive generations, the percentage of non-family executives within the management board increases.

Depending on country-specific characteristics and the legal form of the firm, as well as its specific factors, there is a wide range of terms for the board as well as various modes of organization and composition of this board 
(Corbetta and Salvato, 2004; Koeberle-Schmid et al., 2009; Brenes et al., 2011). In this paper, the term 'supervisory board' will be used. Note that this is different than an advisory board, which has neither legal standing nor a formal role.

According to agency theory, a controlling committee, such as the supervisory board, is required as soon as the interests of the owner and those of the manager differ (Pieper et al., 2008; Achleitner et al., 2010). Should Hypothesis 1 be valid and the conflict of interests increase with subsequent generations, then the importance of supervisory boards increases with each transfer of the firm to another generation (Bammens et al., 2008; Witt, 2008; Achleitner et al., 2010). The increasing level of conflict in successive generations could be handled with the supervisory board's role as an arbitrator (Bammens et al., 2008). However, the rise of the management board's wealth of experience and organizational knowledge (Astrachan et al., 2002; Miller and Le-Breton-Miller, 2006) with each successive generation could lead to the opposite effect (i.e., a lower need for advice) (Bammens et al., 2008). Hence, a generation's need for the advice that boards can provide depends on whether the increasing demand for arbitration is offset by the decreasing need for experience and knowledge or whether it exceeds it.

According to stewardship theory, boards may not motivate stewards and are therefore inefficient (Lee and O'Neill, 2003; Jaskiewicz and Klein, 2007; Pieper et al., 2008). This argument becomes less valid with successive generations as family ties and the attachment to the firm weaken. Similarly, the increase in professionalization that accompanies successive generations should also result in the formation of a supervisory board (Brenes et al., 2011). Therefore, the likelihood of having a supervisory board should increase across generations:

H2: As firm ownership is passed on to successive generations, the firm is more likely to have implemented a supervisory board.

Non-family board members provide better oversight of the management because they are not as bound by the social relationships of the family (Westhead and Howorth, 2006; Koeberle-Schmid et al., 2009). Therefore, with increasing need for control, the number of outside board members will also increase. With decreasing harmony in subsequent generations, the necessity of supervisory boards rises according to stewardship theory.

Furthermore, non-family supervisory board members commonly adopt the role of arbitrators and are associated with objective and independent support (Westhead and Howorth, 2006; Brenes et al., 2011). The higher level of conflicts in successive generations increases the need for such outside arbitration and objectivity. This leads to a higher number of non-family members in boards with later generations:

H3: As firm ownership is passed on to successive generations, the percentage of non-family members on the supervisory board increases.

\section{RESEARCH DESIGN}

\section{Sample}

In this study 5,406 Austrian and 7,550 German enterprises with more than 50 employees were asked to evaluate the research question during the summer of 2009 (Austria) and 2010 (Germany). The CEOs of the firms were invited to participate in the online survey by e-mail. After a first wave of responses, a follow-up e-mail to nonrespondents was sent. In total, 1,422 responses were received, which equals a response rate of $11 \%$. Of the responses, 986 surveys were evaluable. Eighty-nine survey responses had to be eliminated because of missing information regarding the number of employees or because the actual number of employees quoted was lower than 50. In addition, it was not possible to examine the status as a family or non-family business for 85 firms, so those were also excluded from the analysis. The remaining 812 survey responses built the basis of the sample. Non-response bias was controlled by comparing early respondents (first one-third) with late respondents (last one-third) (Leslie, 1972). No significant differences in the response behaviours between these two groups were found; therefore, the sample is representative (Fowler, 2009). For this research, the sample covers family businesses only (445 family firms). 


\section{Methodology}

To test our hypotheses concerning correlation, we applied either the Pearsons's chi-squared test or Fisher's exact test at a significance level of $\alpha=0.05$. To compare percentages in different groups, first a KolmogorovSmirnov test was applied to ensure normal distribution. As all tests for normal distribution were significant (and therefore normal distribution was not confirmed), differences in the mean were analysed with a two-sided MannWhitney test (differences of two means), a one-sided Mann-Whitney test (increasing differences of two means), a Kruskal-Wallis test (difference of more than two means), or a Jonckheere-Terpstra test (testing an increasing trend for more than two means) (Duller, 2008). With the exception of the one-sided Mann-Whitney test, all analyses were performed using SPSS v20.0 (IBM, USA). The one-sided Mann-Whitney test is not available in SPSS software; therefore, R-Software (R Core Team, 2012) with the package "exactRankTests" (Hothorn and Hornik, 2012) was used for this analysis.

\section{EMPIRICAL RESULTS}

naire.

Four different definitions were used to measure generation using two different variables in the question-

The original variable generation has five different values ( $1^{\text {st }}$ founder, $2^{\text {nd }}, 3^{\text {rd }}, 4^{\text {th }}, 5^{\text {th }}$, and after), hereinafter referred to as "generation (5)". For the second definition, generation (5) was dichotomized into the variable "generation (2)" with the two values "founder" and "subsequent" generation. The original variable age was dichotomized into "generation (age25)" following the definition in Blanco-Mazagatos et al. (2010) and Gersick et al. (1997) with a cut-off point at the age of 25 years. The fourth definition "generation (median age)" follows the same idea but has its cut-off point at the median of firm age, which was calculated as 57 years.

\section{Non-Family Executives In Management Board}

Table 1 shows the percentage of non-family managers in the management board according to the different definitions of generation. In general, the descriptive development of the percentage of non-family executives is increasing.

Table 1: Percentage Of Non-Family Executives According To Generation

\begin{tabular}{|l|c|c|c|}
\hline \multicolumn{1}{|c|}{ Generation } & Counts & Non-Family Executives (\%) & Referred To As \\
\hline $1^{\text {st }}$ (founder) & 82 & $24.9 \%$ & Generation(5) \\
\hline $2^{\text {nd }}$ & 144 & $32.2 \%$ & \\
\hline $3^{\text {rd }}$ & 102 & $33.8 \%$ & \\
\hline $4^{\text {th }}$ & 47 & $32.2 \%$ & Generation(2) \\
\hline $5^{\text {th }}$ and subsequent & 39 & $45.3 \%$ & Generation(age25) \\
\hline $1^{\text {st }}$ (founder) & 82 & $24.9 \%$ & Generation(median age) \\
\hline $2^{\text {nd }}$ and subsequent & 332 & $34.2 \%$ & $27.4 \%$ \\
\hline age $\leq 25$ & 67 & $35.1 \%$ & \\
\hline age $>25$ & 334 & $31.4 \%$ & $36.2 \%$ \\
\hline age $\leq$ median & 201 & & \\
\hline age $>$ median & 200 & & \\
\hline
\end{tabular}

Table 2 shows the various tests according to Hypothesis 1. In the first step, it is tested, and if there is a difference in the percentage of non-family executives according to generation, then the hypothesis of an increasing percentage among generations is tested in a second step. 
Table 2: Percentage Of Non-Family Executives, Tests, And Results

\begin{tabular}{|l|c|c|c|c|}
\hline \multicolumn{1}{|c|}{ Definition } & Testing & Test & \multicolumn{2}{c|}{ p-value } \\
\hline generation(5) & differences & Kruskal-Wallis & 0.110 & \\
\hline & increasing & Jonckheere-Terpstra & 0.018 & $* *$ \\
\hline generation(2) & differences & Mann-Whitney (two-sided) & 0.022 & $* *$ \\
\hline generation(age25) & increasing & Mann-Whitney (one-sided) & 0.010 & $* *$ \\
\hline & differences & Mann-Whitney (two-sided) & 0.139 & \\
\hline generation(median age) & increasing & Mann-Whitney (one-sided) & 0.069 & $*$ \\
\hline & differences & Mann-Whitney (two-sided) & 0.180 & \\
\hline
\end{tabular}

According to the Jonckheere-Terpstra test, there is an increasing trend concerning the percentages in subsequent generations. The one-sided Mann Whitney test also shows a significant increase in the percentage of non-family executives between founder and subsequent generations. Measuring generation by means of age is less successful as we have higher p-values for these cases. Thus, generation Hypothesis 1 is supported, but it is not supported with regard to age $(a=0.05)$. Consistent with agency theory and empirical surveys (discussed above in the Impact Of Generation On Governance And Management Accounting: Hypotheses section), the results show an increasing proportion of non-family executives in management boards.

\section{Existence Of A Supervisory Board}

Table 3 presents the percentage of firms within each generation that have implemented a supervisory board. While the first generation has implemented a supervisory board in only $6.0 \%$ of the cases, the percentage increases to $19.5 \%$ in the fifth or subsequent generation. Here, the percentages concerning the existence of a supervisory board between the second and fifth generations indicate a zigzag development.

Table 3: Supervisory Board Among Generations

\begin{tabular}{|l|c|c|}
\hline \multicolumn{1}{|c|}{ Generation } & Count & Supervisory board (\%) \\
\hline $1^{\text {st }}$ (founder) & 83 & $6.0 \%$ \\
\hline $2^{\text {nd }}$ & 145 & $15.9 \%$ \\
\hline $3^{\text {rd }}$ & 102 & $8.6 \%$ \\
\hline $4^{\text {th }}$ & 47 & $19.5 \%$ \\
\hline $5^{\text {th }}$ and subsequent & 41 & $6.0 \%$ \\
\hline $1^{\text {st }}$ founder) & 83 & $14.0 \%$ \\
\hline $2^{\text {nd }}$ and subsequent & 335 & $16.4 \%$ \\
\hline age $\leq 25$ & 67 & $12.7 \%$ \\
\hline age $>25$ & 338 & $14.7 \%$ \\
\hline age $\leq$ median & 204 & $11.9 \%$ \\
\hline age $>$ median & 201 & 2.9 \\
\hline
\end{tabular}

A Pearson's chi-squared test confirmed no dependence or correlation between generation and the existence of a supervisory board. The Kruskal-Wallis test and the Jonckheere-Terpstra test are not statistically significant, indicating neither a difference nor an increasing trend in the likelihood of having a supervisory board in subsequent generations (see Table 4).

Comparing the founder generation with all subsequent generations, there were statistically significant results for dependence, difference, and increase (Table 4). Therefore, subsequent generations are more likely to have a supervisory board than founder generation. Once again, firm age is not as meaningful as generation. Moreover, the likelihood of the existence of a board decreases in older firms (descriptive, not significant). Again, this result is in agreement with agency theory because a higher divergence of goals among family members may lead to the need of a supervisory board to reduce within family conflicts (refer to Impact Of Generation On Governance And Management Accounting: Hypotheses section). 
Table 4: Supervisory Board Among Generations

\begin{tabular}{|l|c|c|c|c|}
\hline \multicolumn{1}{|c|}{ Definition } & Testing & Test & \multicolumn{2}{c|}{ p-value } \\
\hline generation(5) & correlation & Chi-Squared & 0.121 & 0.122 \\
\hline & difference & Kruskal-Wallis & 0.276 & 0.030 \\
\hline & increasing & Jonckheere-Terpstra & 0.048 & $* *$ \\
\hline generation(2) & correlation & Mann-Whitney (two-sided) & 0.030 & $* *$ \\
\hline & difference & Mann-Whitney (one-sided) & 0.262 & 0.417 \\
\hline generation(age25) & increasing & Exact Fisher (one-sided) & 0.844 & \\
\hline & correlation & Mann-Whitney (two-sided) & 0.251 & \\
\hline generation(median age) & difference & Mann-Whitney (one-sided) & 0.414 & \\
\hline & increasing & Exact Fisher (one-sided) & 0.833 & \\
\hline
\end{tabular}

\section{Percentage Of Non-Family Members In Supervisory Boards}

For the next section of results, some limitations should first be discussed at this point in order to avoid wrong conclusions from the results. Unfortunately, the non-response rate for the question concerning the composition of the supervisory board was very high. As the majority of the non-respondents answered the following questions, it can be assumed that the respondents did not know the exact composition of the board, especially whether a member of the board is a family member. Thus, due to the low response rate and the low number of cases, the next set of results presented has to be discussed very carefully.

The results again show a descriptive portion and information on several tests. Table 5 presents the results concerning the percentage of non-family members on the supervisory board. In all cases, the majority of the board are non-family members. Again, the trends concerning generation and age are inversely related. While generation shows a decreasing trend in non-family members on a supervisory board, age shows an increasing trend.

Table 5: Percentage Of Non-Family Members On The Board

\begin{tabular}{|l|c|c|}
\hline \multicolumn{1}{|c|}{ Generation } & Counts & Non-Family Member In Board (\%) \\
\hline $1^{\text {st }}$ (founder) & 5 & $86.7 \%$ \\
\hline $2^{\text {nd }}$ & 22 & $70.4 \%$ \\
\hline $3^{\text {rd }}$ & 12 & $64.4 \%$ \\
\hline $4^{\text {th }}$ & 4 & $70.1 \%$ \\
\hline $5^{\text {th }}$ and subsequent & 8 & $86.7 \%$ \\
\hline $1^{\text {st }}$ (founder) & 8 & $71.4 \%$ \\
\hline $2^{\text {nd }}$ and subsequent & 46 & $65.7 \%$ \\
\hline age $\leq 25$ & 10 & $73.6 \%$ \\
\hline age $>25$ & 43 & $68.5 \%$ \\
\hline age $\leq$ median & 29 & $76.5 \%$ \\
\hline age $>$ median & 24 & \\
\hline
\end{tabular}

All tests were not significant (see Table 6); therefore, Hypothesis 3 is rejected. There is no significant difference in the composition of supervisory boards concerning family and non-family members among subsequent generations. Moreover, the percentage of non-family members is decreasing with regard to generation (descriptive).

Table 6: Percentage Of Non-Family Members On The Board

\begin{tabular}{|l|l|l|l|l|}
\hline Definition & Testing & Test & \multicolumn{2}{l|}{ p-value } \\
\hline generation(5) & correlation & Kruskal-Wallis & 0.858 & \\
\hline & increasing & Jonckheere-Terpstra & 0.539 & \\
\hline generation(2) & correlation & Mann-Whitney (two-sided) & 0.271 & \\
\hline generation(age25) & increasing & Mann-Whitney (one-sided) & 0.864 & \\
\hline & correlation & Mann-Whitney (two-sided) & 0.329 & \\
\hline generation(median age) & increasing & Mann-Whitney (one-sided) & 0.169 & \\
\hline & correlation & Mann-Whitney (two-sided) & 0.459 & \\
\hline
\end{tabular}




\section{CONCLUSION}

This study attempted to research the impact of a family firm's incumbent generation on its governance mechanisms. The percentages of non-family executives increase significantly with subsequent generations and increase, but not significantly with firm age. In general, subsequent generations have more non-family executives on the management board than the founder generation.

With successive generations, the likelihood of an implemented supervisory board increases, but only the difference between the founder and subsequent generation was significant. Implementation within subsequent generations is not linear, but rather a curve with peaks and valleys. The trend concerning non-family members on the board is in the opposite direction of having a board at all; therefore, subsequent generations are more likely to have a supervisory board, but the percentage of non-family members on the board decreases.

In contrast to most other studies, which only differentiate between three categories - namely, 'first', 'second', and 'third and subsequent generations' - this study also analysed the third and fourth generations separately. Secondly, further insights into the widely neglected research area of management accounting in family firms are provided. While most of the research on generational issues has been limited to the USA and the UK, this survey used Austrian and German data, therefore contributing to the growing body of European analyses (e.g., Suáre and Santana-Martín, 2004; Voordeckers et al., 2007; Bammens et al., 2008) that focus on governance aspects. Finally, the results show the limitation of defining generation by firm age. This study had the fortunate situation of having both variables in one sample, but of the three results, only one was similar concerning generation and age; the remaining two results showed opposite trends.

This study has some limitations that should be acknowledged and addressed in future research. First of all, the classification of generations could be more precise to make it possible to control for hybrid forms (multigenerational firms with members from more than one generation). Moreover, future analyses should research the differences between family members of a particular generation, such as personal characteristics, attitudes, goals, and values, in more detail.

\section{ACKNOWLEDGEMENTS}

The author thanks the participants of the 11th Annual IFERA World Family Business Research Conference in Palermo (2011) and of the IABE summer conference in Barcelona (2011) for helpful comments on earlier versions of this paper.

\section{AUTHOR INFORMATION}

Christine Duller is Assistant Professor at the Institute of Applied Statistics at the Johannes Kepler University Linz, Austria. Her main areas of research include management accounting in family firms, applied statistics and teaching statistics. E-mail: christine.duller@jku.at

\section{REFERENCES}

1. Achleitner, A.-K., Bock, C., Braun, R., Schraml, S. and Welter, J. (2010). Goal Structures in Family Firms: Empirical Evidence on the Relationship between Firm and Family Goals. CEFS Working Paper Series, 5, $1-28$.

2. Anderson, R. C. and Reeb, D. M. (2003). Founding family ownership and firm performance: Evidence from the S\&P 5000. Journal of Finance, 58(3) 1301-1328.

3. Anderson, R. C., Mansi, S. A. and Reeb, D. M. (2003). Founding family ownership and the agency cost of debt. Journal of Financial Economics, 68(2) 263-285.

4. Astrachan, J. H. and Shanker, M. C. (2003). Family Businesses' Contribution to the U.S. Economy: A Closer Look. Family Business Review, 16(3) 211-219.

5. Astrachan, J. H. (2003). Commentary on the special issue: the emergence of a field. Journal of Business Venturing, 18(3) 567-572. 
6. Astrachan, J. H., Klein, S. B. and Smyrnios, K. X. (2002). The F-PEC Scale of family influence: A proposal for solving the family business definition problem. Family Business Review, 15(1) 45-58.

7. Bammens, Y., Voordeckers, W. and Van Gils, A. (2008). Board of directors in family firms: a generational perspective. Small Business Economics, 31(2) 163-180.

8. Bartholomeusz, S. and Tanewski, G. A. (2006). The Relationship between Family Firms and Corporate Governance. Journal of Small Business Management, 44(2) 245-267.

9. Beckhard, R. and Dyer, G. W. (1983) Managing Continuity in the Family-Owned Business. American Management Association, 60(1) 5-12.

10. Blanco-Mazagatos, V., de la Fuente-Sabaté, J. M., and de Quevedo-Puente, E. (2010). Finance in family firms: generation does matter. International Journal of Entrepreneurship and Small Business, 11(3) 338352.

11. Brenes, E. R., Madrigal, K. and Requena, B. (2011). Corporate Governance and Family Business Performance. Journal of Business Research, 64(3) 280-285.

12. Chrisman, J. J., Chua, J. H. and Sharma, P. (2003). Current trends and future directions in family business management studies: Toward a theory of the family firm. Cole Whiteman Paper Series, retrieved from: http://www.usasbe.org/knowledge/whitepapers/chrisman2003.pdf

13. Chrisman, J. J., Chua, J. H., and Sharma, P. (2005). Trends and Directions in the Development of a Strategic Management Theory of the Family Firm. Entrepreneurship Theory \& Practice, 29(5) 555-576.

14. Corbetta, G. and Salvato, C. A. (2004). The Board of Directors in Family Firms: One Size Fits All? Family Business Review, 17(2) 119-134.

15. Davis, J. H., Schoorman, D. F. and Donaldson, L. (1997). Toward a Stewardship Theory of Management. Academy of Management Review, 22(1) 20-47.

16. Davis, P. S. and Harveston, P. D. (1999). In the Founder's Shadow: Conflict in Family Firms. Family Business Review, 12(4) 311-323.

17. Debicki, B. J., Matherne, C. F., Kellermanns, F. W. and Chrisman, James J. (2009). Family Business Research in the New Millennium: An Overview of the Who, the Where, the What and the Why. Family Business Review, 22(2) 151-166.

18. Duller, C. (2008). Einführung in die nichtparametrische Statistik mit SAS und R, Heidelberg: Physica.

19. Duller, C., Feldbauer-Durstmüller, B. and Mitter, C. (2011). Corporate Governance and Management Accounting in Family Firms: Does Generation matter? International Journal of Business Research, 11(1) 29-46.

20. Dyer, G. W. Jr. (1988). Culture and Continuity in Family Firms. Family Business Review, 1(1) 37-50.

21. Dyer, G. W. Jr. (2003). The Family: The Missing Variable in Organizational Research. Entrepreneurship Theory \& Practice, 27(4) 401-416.

22. Eisenhardt, K. M. (1989). Agency Theory: An Assessment and Review. Academy of Management Review, 14(1) 57-74.

23. Fowler, F. J. (2009). Survey Research Methods. 4th ed., Thousand Oaks: Sage.

24. Gersick, K. E., Davis, J. A., McCollom Hampton, M. and Lansberg, I. (1997). Generation to Generation: Life Cycles of the Family Business. Boston, MA: Harvard Business School Press.

25. Heck, R. K. Z. and Trent, E. S. (1999). The Prevalence of Family Business from a Household Sample. Family Business Review, 12(3) 209-219.

26. Hothorn, T. and Hornik K. (2012). exactRankTests: Exact Distributions for Rank and Permutation Tests. R package version 0.8-23. Retrieved from: http://CRAN.R-project.org/package=exactRankTests

27. Ibrahim, N. A., Angelidis, J. P. and Parsa, F. (2008). Strategic Management of Family Businesses: Current Findings and Directions for Future Research. International Journal of Management, 25(1) 95-110.

28. Jacobides, M. G. and Croson, D. C. (2001). Information Policy and Shaping the Value of Agency Relationships. Academy of Management Review, 36(2) 202-223.

29. Jaskiewicz, P. and Klein, S. B. (2007). The impact of goal alignment on board composition and board size in family businesses. Journal of Business Research, 60(10) 1080-1089.

30. Jensen, M. C. and Meckling, W. H. (1976). Theory of the Firm: Managerial Behavior, Agency Costs and Ownership Structure. Journal of Financial Economics, 3(4) 305-360.

31. Karra, N., Tracey, P. and Phillips, N. (2006). Altruism and Agency in the Family Firm: Exploring the Role of Family, Kinship and Ethnicity. Entrepreneurship Theory \& Practice, 30(6) 861-877. 
32. Klein, S. B. (2000). Family Business in Germany: Significance and Structure. Family Business Review, 13(3) 157-182.

33. Koeberle-Schmid, A., Brockhoff, K. and Witt, P. (2009). Performanceimplikationen von Aufsichtsgremien in deutschen Familienunternehmen. Zeitschrift für Betriebswirtschaft, 79, Special Issue 2, 83-111.

34. Lane, S., Astrachan, J., Keyt, A. and McMillan, K. (2006). Guidelines for Family Business Boards of Directors. Family Business Review, 19(2) 147-167.

35. Le Breton-Miller, I. and Miller, D. (2009). Agency vs. Stewardship in Public Family Firms. A Social Embeddedness Reconciliation. Entrepreneurship Theory \& Practice, 33(6) 1069-1091.

36. Lee, P. M. and O’Neill, H. M. (2003). Ownership Structures and R\&D Investments of U.S. and Japanese Firms: Agency and Stewardship Perspectives. Academy of Management Journal, 46(2) 212-225.

37. Leslie, L. L. (1972). Are high response rates essential to valid surveys? Social Science Research, 1(3) $323-$ 334.

38. Lubatkin, M. H., Schulze, W. S., Ling, Y. and Dino, R. N. (2005). The effects of parental altruism on the governance of family-managed firms. Journal of Organizational Behavior, 26(3) 313-330.

39. Lussier, R. N. and Sonfield, M. C. (2010). A six-country study of first-, second-, and third-generation family businesses. International Journal of Entrepreneurial Behaviour \& Research, 16(5) 414-436.

40. Lutz, E., Schraml, S. and Achleitner, A.-K. (2010). Loss of Control vs. Risk Reduction - Decision Factors for Hiring Non-Family CFOs in Family Firms. Working Paper Series Center for Entrepreneurial and Financial Studies, 4 1-30.

41. Miller, Da. and Le Breton-Miller, I. (2006). Family Governance and Firm Performance: Agency, Stewardship, and Capabilities. Family Business Review, 19(1) 73-87.

42. Pieper, T. M., Klein, S. B. and Jaskiewicz, P. (2008). The Impact of Goal Alignment on Board Existence and Top Management Team Composition: Evidence from Family-Influenced Businesses. Journal of Small Business Management, 46(3) 372-394.

43. R Core Team (2012), R: A language and environment for statistical computing. R Foundation for Statistical Computing, Vienna, Austria. Retrieved from: http://www.R-project.org/

44. Salvato, C. and Melin, L. (2008). Creating Value Across Generations in Family-Controlled Businesses: The Role of Family Social Capital. Family Business Review, 21(3) 259-275.

45. Schein, E. H. (1983). The Role of the Founder in Creating Organizational Culture. American Management Association, 60(1) 13-28.

46. Schulze, W. S., Lubatkin, M. H. and Dino, R. N. (2003). Toward a theory of agency and altruism in family firms. Journal of Business Venturing, 18(4) 473-490.

47. Sirmon, D. G., Arregle, J.-L., Hitt, M. A. and Webb, J. W. (2008). The Role of Family Influence in Firms' Strategic Responses to Threat of Imitation. Entrepreneurship Theory \& Practice, 32(6) 979-998.

48. Suáre, K.C. and Santana-Martín, D.J. (2004). Governance in Spanish family business. International Journal of Entrepreneurial Behaviour \& Research, 10(1/2) 141-163.

49. Ulaner, L., Floren, R. H. and Geerlings, J. R. (2007). Owner commitment and relational governance on the privately-held form: An empirical study. Small Business Economics, 29(3) 275-293.

50. Vallejo, M. C. (2009). The Effect of Commitment of Non-Family Employees of Family Firms from the Perspective of Stewardship Theory. Journal of Business Ethics, 87(3) 379-390.

51. Van den Berghe, L.A.A. and Carchon, S. (2002). Corporate Governance Practices in Flemish Family Businesses. Corporate Governance: An International Review, 10(3) 225-245.

52. Villalonga, B. and Amit, R. (2006). How do family ownership, control and management affect firm value? Journal of Financial Economics, 80(2) 385-417.

53. Voordeckers, W., Van Gils, A. and van den Heuvel, J. (2007). Board Composition in Small and MediumSized Family Firms. Journal of Small Business Management, 45(1) 137-156.

54. Westhead, P. and Howorth, C. (2006). Ownership and Management Issues Associated With Family Firm Performance and Company Objectives. Family Business Review, 19(4) 301-316, 2006.

55. Witt, P. (2008). Corporate Governance in Familienunternehmen, Zeitschrift für Betriebswirtschaft, 78, Special Issue 2, 1-19. 


\section{NOTES}

